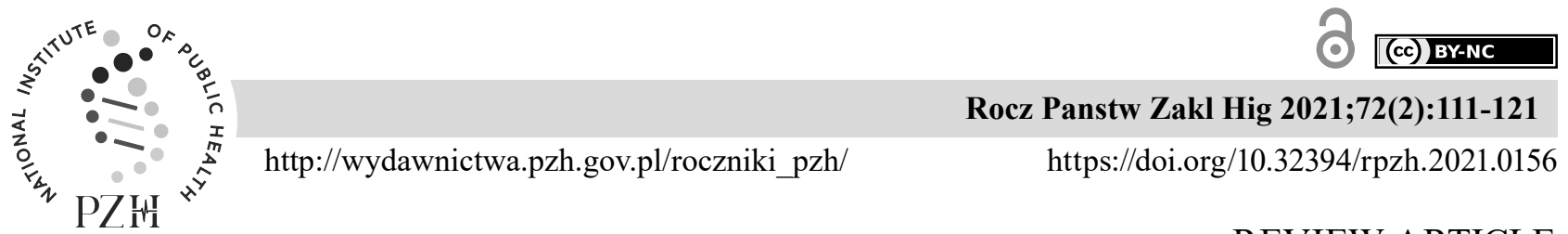

REVIEW ARTICLE

\title{
THE ROLE OF VITAMIN D IN SELECTED AUTOIMMUNE DISEASES
}

\author{
Aleksandra Wiśniewska ${ }^{1}$ Alicja Szypowska
}

${ }^{1}$ Wrocław Medical University, Students Scientific Club at the Department of Dietetics, Wrocław, Poland

${ }^{2}$ Wroclaw Medical University, Department of Dietetics, Wrocław, Poland

\begin{abstract}
The authors of recently published scientific papers are focusing increasingly often on the effect of vitamin D on immune processes. In the case of deficiencies of this vitamin, an imbalance in the immune system is observed, which is associated with the intensification of the inflammatory reaction in the body and the increased possibility of an autoimmune reaction. Therefore, due to the growing interest of scientists in the relationship between the effects of vitamin D and the development of autoimmune diseases, this paper considers the use of Vitamin D in autoimmune therapies. However, the mechanism of vitamin D on individual autoimmune diseases has not been elucidated so far, therefore there is a need for further research. The importance of maintaining normal plasma vitamin D levels to reduce the risk of developing autoimmune diseases has been demonstrated by the authors of other studies. They showed that vitamin D levels influenced the course, severity of symptoms and frequency of relapses of autoimmune thyroid disease, inflammatory bowel disease, and rheumatoid arthritis.
\end{abstract}

Key words: vitamin D, autoimmunity, rheumatoid arthritis, inflammatory bowel disease, autoimmune Hashimoto's thyroiditis, autoimmune thyroid disorder

\section{STRESZCZENIE}

Autorzy prac naukowych, opublikowanych w ostatnim czasie, coraz częściej skupiają się na wpływie witaminy D na procesy immunologiczne. W przypadku wystąpienia niedoborów tej witaminy obserwuje się upośledzenie równowagi działania układu immunologicznego, co wiąże się z nasileniem reakcji zapalnej w organizmie i zwiększeniem możliwości wystąpienia reakcji autoimmunologicznej. Ze względu na rosnące zainteresowanie naukowców tematem zależności występujących pomiędzy działaniem witaminy D a rozwojem chorób autoimmunologicznych rozważa się wykorzystanie tej witaminy w ich terapii. Mechanizm wpływu witaminy D na poszczególne choroby autoimmunologiczne nie został dotychczas wyjaśniony, dlatego istnieje potrzeba przeprowadzenia dalszych badań. Istotne jest utrzymanie prawidłowego stężenia witaminy D w osoczu w celu zmniejszenia ryzyka rozwoju chorób autoimmunologicznych. Powyższy wniosek został wykazany przez autorów badań w odniesieniu do autoimmunologicznych chorób tarczycy, nieswoistych chorób jelit oraz reumatoidalnego zapalenia stawów. Stężenie witaminy D wpływało na przebieg tych chorób, nasilenie objawów oraz częstotliwość występowanie nawrotów.

Słowa kluczowe: witamina $D$, autoimmunizacja, reumatoidalne zapalenie stawów, nieswoiste zapalenia jelit, choroba Hashimoto, choroby autoimmunologiczne tarczycy

\section{INTRODUCTION}

Vitamin D is an essential vitamin that is necessary in the proper functioning of the body. It performs many important functions by influencing the course of basic metabolic processes, as a result ensuring the proper functioning of the body. The range of vitamin D's activity in the body depends on its serum concentration. Vitamin D deficiencies are often an indirect cause in the multistage pathogenesis of diseases, and its supplementation is crucial for preventing these diseases $[1,2,5,13,20,21,39,47,4$ $9,53]$.

The most widely described function of vitamin $D$ is its effect on calcium-phosphate metabolism and its role in the prevention of rickets and osteoporosis [49]. However, the authors of recently published scientific papers are increasingly focusing on the effect of vitamin $\mathrm{D}$ on immune processes, including autoimmune diseases. In the event of vitamin D deficiencies, an impairment of the immune system balance is observed, which is associated with

Corresponding author: Alicja Szypowska, Wroclaw Medical University, Department of Dietetics, Wrocław, Poland, Tel.+ 4871348 35 30, e-mail: alicja.szypowska@umed.wroc.pl,

(C) Copyright by the National Institute of Public Health - National Institute of Hygiene 
intensification of the inflammatory reaction in the body and the increased possibility of an autoimmune reaction. The correct vitamin $\mathrm{D}$ level in the blood determines the secretion of anti-inflammatory cytokines and regulatory elements of the immune system. The serum vitamin D levels also have an indirect effect on, among other things, the microbiome and the integrity of the intestinal epithelial barrier. In the case of a deficiency of vitamin D in the plasma, this relationship can have an effect on the development of autoimmune reactions. Due to the growing interest of scientists in the relationship between the effects of vitamin $\mathrm{D}$ and the development of autoimmune diseases, this paper considers the use of Vitamin D in autoimmune therapies. The mechanism of vitamin $\mathrm{D}$ on individual autoimmune diseases has so far not been elucidated, therefore there is a need for further research $[1,8,9,14,31,51,55,59]$.

The aim of this study is to review the scientific literature with regard to the effects of plasma vitamin $\mathrm{D}$ levels on the immune system, pathogenesis, and development of autoimmune diseases, such as autoimmune thyroid disease, inflammatory bowel disease (IBDs), and rheumatoid arthritis (RA).

\section{VITAMIN D - METABOLISM AND BIOLOGICAL FUNCTIONS}

Vitamin D is part of a specific group of compounds known as secosteroid compounds. The term "vitamin D" refers to two main compounds, ergocalciferol (vitamin $\mathrm{D}_{2}$ ) and cholecalciferol (vitamin $\mathrm{D}_{3}$ ). Both molecules have an analogous structure, consisting of $\mathrm{A}, \mathrm{B}, \mathrm{C}, \mathrm{D}$ rings and a side chain. Vitamin $\mathrm{D}$ is considered to be a secosteroid compound because of the presence of a characteristic, open B chain. The ergocalciferol and cholecalciferol are synthesized from provitamins - ergosterol and 7-dehydocholesterol, respectively - under the influence of ultraviolet B radiation of a specific wavelength. The central point of the process of converting provitamins into vitamins is a modification within the molecule B-ring by thermal isomerization $[17,25,33,46]$. Vitamin D supplied to the body undergoes numerous metabolic processes, thanks to which it reaches its active form [25].

Ergocalciferol, a derivative of exogenous ergosterol, differs from cholecalciferol in the structure of its side chain, but both forms undergo the same metabolic process pathways $[17,25,46]$. The vitamin $\mathrm{D}_{3}$ precursor, which is 7-dehydrocholesterol, is mainly found in keratinocytes and fibroblasts. The reaction of 7-dehydrocholesterol conversion into its active form of cholecalciferol (calciol) takes place in the skin under the influence of UVB radiation with an appropriate wavelength of $290-315 \mathrm{~mm}$. The resulting calciol molecule has a lasting and stable structure, and is then released into the intercellular space to be further transported in the blood [25].

The next stage of metabolic transformations is the double enzymatic hydroxylation reaction which takes place in the liver and kidneys. The first hydroxylation reaction takes place in the liver, catalyzed by the vitamin D 25-hydroxylase enzyme. The product of this reaction is 25-hydroxy-cholecalciferol (calcidiol), with a chemical formula of $25(\mathrm{OH}) \mathrm{D}_{3}$. Calcidiol is the main form of vitamin D found in the blood serum. The second hydroxylation reaction takes place in the kidneys with the participation of $1 \alpha$-hydroxylase. During this reaction, the A-ring of the molecule is hydroxylated, and a compound called calcitriol, otherwise known as $1 \alpha, 25$-dihydroxycholecalciferol, is formed with the chemical formula $1 \alpha, 25(\mathrm{OH})_{2} \mathrm{D}_{3}$. The reaction is controlled by parathyroid hormone $(\mathrm{PTH})$, the metabolism of which depends on the concentration of $1 \alpha, 25(\mathrm{OH})_{2} \mathrm{D}_{3}$ calcium, and phosphate content in the blood serum [25].

The vitamin D receptor (VDR receptor) is part of a group of steroid hormone receptors that includes vitamin $\mathrm{D}$. Through this receptor, vitamin $\mathrm{D}$ acts on target cells of the body [25]. The VDR receptors have been detected in a large number of tissues, including adipose tissue, skin, cells of the immune system, and the placenta. The largest number of receptors are found within the endocrine and digestive systems, especially in the small intestine, which fact proves the specific effect of vitamin $\mathrm{D}$ in these areas $[10,56]$.

The effect of vitamin $\mathrm{D}$ at the genomic level is related to the effect of the VDR/RXR complex. It is a combination of the vitamin $\mathrm{D}$ receptor (VDR) and the retinoid $\mathrm{X}$ receptor (RXR), which forms a heterodimer complex. The complex is activated by $1 \alpha, 25(\mathrm{OH})_{2} \mathrm{D}_{3}$, which shows an analogous activity to the transcription factor. An example of an action of the $1 \alpha, 25(\mathrm{OH})_{2} \mathrm{D}_{3} / \mathrm{VDR}$ complex is its effect on bone remodeling [3]. The particular effect of VDR/ RXR complex has also been observed in the case of so-called transcriptional pathways, for example, cytokine-activated pathways. Additionally, vitamin D can modulate such immunological processes as autophagy and apoptosis [7].

Vitamin D can control its own level through the VDR receptor using negative feedback. In the process, $1,25(\mathrm{OH})_{2} \mathrm{D}$ inhibits expression and synthesis of the parathyroid hormone. As a consequence $1 \alpha$-hydroxylase synthesis in the kidneys is decreased. $1 \alpha$-hydroxylase is responsible for the major stage of the vitamin D synthesis process. The vitamin D 25-hydroxylase enzyme is responsible for the degradation of calciferol, which causes catabolic reactions. As a result, a water-soluble inactive metabolite is formed. The produced metabolite is excreted from the body along with bile [10] 
Calcitriol is a substance with hormone properties, including the ability to bind to the VRD receptor, which acts as a transcription factor and is necessary for vitamin $\mathrm{D}$ to induce biological effects $[3,48]$.

\section{THE EFFECT OF VITAMIN D ON THE IMMUNE SYSTEM}

The immune system works by controlling processes in all body systems. The enzyme 1- $\alpha$-hydroxylase and the VDR receptor that activate vitamin D have been detected in many cells of the immune system. The presence of VDR receptors has been detected in monocytes, antigen-presenting cells, as well as $\mathrm{T}$ and B lymphocytes. The highest content of VDRs in the immune system is observed in monocytes and antigen-presenting cells [51,56].

The mechanism of vitamin $D$ on cells of the nonspecific immune response

Innate immunity, otherwise known as nonspecific immunity, is the body's first line of defense. The mechanisms of non-specific immunity act immediately, but are not very precise. The main line of defense in the case of this type of immune mechanism are phagocytic cells (macrophages, granulocytes), the complement system, lysozyme, interferon and cells capable of cytotoxicity [31].

\section{Macrophages}

Vitamin D stimulates the maturation of phagocytic cells and their transition to the macrophages' active form. A deficiency of vitamin D is associated with inhibition of the secretion of lysosomal enzymes and $\mathrm{H}_{2} \mathrm{O}_{2}$, which are essential factors in the phagocytosis of pathogens by macrophages [45]. Because of their functions in the immune system, macrophages are referred to as phagocytic and antigen-presenting cells. In the event of an infection, the macrophages' action has two steps: production of pro-inflammatory cytokines, and mobilization of other cells of the immune system. With regards to the functional profile of the cytokines they produce, we distinguish two groups of macrophages. The first are M1 macrophages that produce pro-inflammatory cytokines, such as interleukin 12 (IL-12), interleukin 1 (IL-1), tumor necrosis factor $\alpha(\mathrm{TNF} \alpha)$ and interleukin 23 (IL-23). The cytokines take an active part in the elimination of pathogens and also have an effect on T-cell differentiation. The other, M2 subgroup macrophages, are mainly responsible for the anti-inflammatory activity by producing interleukin 10 (IL-10) [44].

In the case of autoimmune diseases, changes in the distribution and number of macrophages of a specific subtype are observed. In the area of inflammation, there is an increase in the number of macrophages and macrophage-dependent lymphocytic cells. The loss of balance between M1 and M2 macrophages is also observed. The appropriate concentration of $1,25(\mathrm{OH})_{2} \mathrm{D}_{3}$ in the body restores the balance between the activities of the M1 and M2 macrophages. This restoration occurs through the reduced production of pro-inflammatory factors by M1 macrophages and increased synthesis of anti-inflammatory cytokines produced by M2 macrophages. This macrophage regulation results in anti-inflammatory effects which prevent the excessive reactivity of M2 macrophages, while also maintaining the correct immune response mechanisms of the body [14].

Calcitriol also has an effect on the synthesis of cathelicidin and defensin antimicrobial peptides. The process of synthesizing an antimicrobial peptide controlled by vitamin D concentration begins with identification of the pathogen. Using toll-like receptors (TRL), macrophages and monocytes capture the pathogen. The TRL receptor is assisted by cytokines produced by $\mathrm{T}$ lymphocytes, and causes transition of the vitamin $\mathrm{D}$ precursor to its active form and its binding to the VDR receptor. Among the cytokines, interferon $\gamma($ IFN- $\gamma$ ) has an active effect on vitamin D metabolism, while interleukin 4 (IL-4) has an inhibitory effect. Vitamin D bound to the VRD receptor binds to the retinoid $\mathrm{X}$ receptor, stimulating the synthesis of the antimicrobial peptide. The resulting cathelicidin has an antibacterial effect and influences the immune system's neutralization of pathogenic microorganisms [16, 22, 51]. Wang et al. [57] showed that vitamin D also influences the synthesis of $\beta_{2}$ defensin by stimulating receptors for the molecular patterns nucleotidebinding oligomerization domain containing $2\left(\mathrm{NOD}_{2}\right)$, responsible for the activation of $\beta_{2}$ defensin synthesis.

\section{Dendritic cells}

Dendritic cells stimulate specific immunity cells multidirectionally, however, the most important factor is immunostimulation, which is dendritic cells' ability to transform into a tolerogenic state. However, calcitriol can weaken their ability to immunostimulate - under calcitrol's influence, the expression of surface molecules that are necessary for the presentation of the antigen is weakened. In addition, the synthesis of pro-inflammatory cytokines (such as IL-6, -12, -23), is inhibited with a simultaneous increase in the synthesis of anti-inflammatory factors (IL-10, prostaglandin $\mathrm{E}_{2}: \mathrm{PGE}_{2}$, chemokine CCL22). Tolerogenic dendritic cells regulate the production of regulatory $\mathrm{T}$ cells (Treg), which are responsible for regulation of immune processes and control autoimmune reactions. These elements of the immune system influence the maintenance of the immune balance and support the regulation of autoimmune processes in the human body $[1,9,23,24]$. 
Zhongxiang et al. [62] demonstrated the effect of vitamin D-induced telerogenic dendritic cells on immunological processes in multiple sclerosis (MS). Their study was performed on animal models using experimental autoimmune encephalomyelitis (EAE) material. Researchers collected blood from EAEinfected dead mice and grew populations of dendritic cells from bone marrow cells. The cells were made tolerogenic under the influence of vitamin D. The researchers then created three groups: a control group, a group with dendritic cells administered, and a group with dendritic cells administered in the presence of $1,25(\mathrm{OH})_{2}$. The scientists reported the effect of tolerogenic dendritic cells in the presence of $1,25(\mathrm{OH})_{2}$ in mice in the form of an increased number of IL-10 secreting $\mathrm{T}$ helper 2 (Th2) cells and regulatory B lymphocytes produced in the spleen. Less penetration and activity of T helper 1 (Th1) and T helper 17 (Th17) cells in the area of the spinal cord were also observed. The authors speculate that vitamin D-induced tolerogenic dendritic cells alleviate EAE. In addition, the authors believe that in the future, use of this type of therapy could be introduced into autoimmune diseases therapy. However, the form of therapy presented above requires further research.

As a result of the action of vitamin $\mathrm{D}$, antiinflammatory and regulatory effects are stimulated, which are key in the autoimmune process. Therefore, the tolerogenic dendritic cells formed under the influence of vitamin $\mathrm{D}$ are being considered for use in autoimmune disease therapy $[14,26,30]$.

\section{The effect of vitamin D on selected elements of specific immune responses}

Specific immunity is not an immediate reaction. Specific immune mechanisms are targeted precisely against a specific antigen. This type of immune reaction uses antibodies produced by $\mathrm{B}$ lymphocytes and $\mathrm{T}$ lymphocytes. In the case of specific immunity, there is also a secondary specific response. This response is the immediate response of the immune system to repeated contact with a given antigen [31].

\section{B lymphocytes}

The effect of $1,25(\mathrm{OH})_{2} \mathrm{D}_{3}$ on $\mathrm{B}$ lymphocytes is dependent on whether the cell is activated or resting. Calcitriol inhibits the proliferation of activated B lymphocytes, resulting in reduced production of immunoglobulins. In addition, calcitriol also significantly influences the activation of the apoptosis process of B lymphocytes, and inhibits the differentiation of plasma cells present in the maturation and proliferation stage. Vitamin D reduces the amount and production of antibodies, but does not affect the existing antibodies. The effect of vitamin D on B lymphocytes via VDRs depends on the duration of the action and its concentration, as well as on the developmental stage of B lymphocytes [12, 45].

In autoimmune diseases, $\mathrm{B}$ lymphocytes are responsible for the production of antibodies against the body's own antigens. The mechanism of vitamin $\mathrm{D}$ is based on its effect on the main stage of B lymphocytes' formation, by which it prevents the differentiation of plasma cells. For this reason, it inhibits the production of antibodies in the autoimmune process [14].

\section{T lymphocytes}

The effect of $1,25(\mathrm{OH})_{2} \mathrm{D}_{3}$ on $\mathrm{T}$ lymphocytic cells can cause changes in the synthesis of specific cytokine profiles mediated by $\mathrm{T}$ helper cells (Th), and also affect VDR expression. Naive CD4+ T cells are differentiated functionally by cytokines, the secretion of which is controlled by vitamin D. Vitamin D inhibits IFN- $\gamma$ synthesis and activates IL-4, as a result of which increased Th2 lymphocyte synthesis and decreased Th1 lymphocyte synthesis can observed. Vitamin D also inhibits Th17 synthesis and activates increased Treg synthesis [40].

Th1s are lymphocytes that synthesize interleukin 2 (IL-2), IFN $\gamma$, interferon $\alpha($ IFN- $\alpha)$. While Th2 lymphocytes synthesize interleukin 3 (IL-3), IL4, interleukin 5 (IL-5) and IL-10. T cells that secrete interleukin 17 (IL-17) are Th17 lymphocytes. Vitamin D affects the suppression of IL-17 transcription during gene expression, thus reducing the production of IL-17. The inhibition of IL-17 synthesis results in the reduction of autoimmune processes in the body [36]. The correct vitamin D level regulates the physiologically correct balance of cytokine production [28].

Treg lymphocytes are responsible for stimulating the correct immune response. Their mechanism is part of the control of inflammatory processes, reactivity and sensitivity to the body's own antigens. Vitamin D can affect the synthesis of Treg lymphocytes by antigen-presenting cells or by expression of genetic factors conditioning the synthesis of regulatory $T$ lymphocytes. Antigen-presenting cells increase the synthesis of IL-10, which stimulates the synthesis of Treg. Vitamin D can influence the transcription factor Forkhead box protein E3 (FOXE3, which determines the secretion of Treg $[12,45]$.

It has been suggested that $1,25(\mathrm{OH})_{2} \mathrm{D}_{3}$ has an immunomodulatory effect. Prietl et al. [50] assessed whether high-dose supplementation with vitamin $\mathrm{D}_{3}$ has an effect on autoimmune processes by influencing the mechanism of regulatory lymphocytes CD4+ FoxP3+ (Treg). 60 healthy people were qualified for the study and were randomly divided into two groups. The study group $(n=30)$ received vitamin $D_{3}(140,000$ $\mathrm{IU} /$ month), while the control group $(\mathrm{n}=30)$ received a placebo. Prietl et al. [50] also assessed the safety of this supplementation and its effect on the metabolism 
of other immune cells (including monocytes, dendritic cells). After 3 months, a $116 \%$ increase in the vitamin $\mathrm{D}_{3}$ level in serum was observed in the study group. Additionally, in these patients, an increase in regulatory $T$ cells was assessed, which was not interfering with the function of other immune cells. The appropriate serum $25(\mathrm{OH}) \mathrm{D}$ concentration was associated with an increase in Treg cells, which are crucial in the treatment of autoimmune diseases.

\section{THE RELATIONSHIP BETWEEN THE IMMUNE RESPONSE AND GUT MICROBIOTA}

Vitamin D has an effect on the condition of connections of the intestinal epithelial cells. The action of vitamin D increases the synthesis of the zonulin protein. Zonulin connects intestinal epithelial cells and determines the connections integrity with the intestinal epithelial tissue. Increasing the connections integrity between the epithelial cells reduces the penetration of pathogens through the intestinal barrier, which significantly reduces the possibility of inflammation. The described mechanism exerts a significant effect on immunological processes and is considered a predisposing factor in the occurrence of autoimmune diseases. Changes in serum vitamin D levels affect the barrier in different, often opposite ways. Vitamin D deficiency may be associated with the increased permeability of the intestinal wall to pathogenic substances, resulting in a decreased antiinflammatory effect, which may then contribute to the intensification of autoimmune processes [59, 61].

Genetic predispositions can influence the metabolism and concentration of vitamin $\mathrm{D}$, the connection integrity of intestinal epithelial cells, and the immune activity level in the body. Low plasma vitamin D levels increase the penetration of microorganisms through the intestinal epithelium walls, and also stimulates immune activity. The stimulated immune activity increases the likelihood of an autoimmune reaction. On the other hand, the increased penetration of pathogenic substances through the intestinal walls indirectly increases the body's immune activity, which can lead to the development of autoimmune diseases. A deficiency of vitamin $\mathrm{D}$ also influences changes in the microbiome composition, which increases the microbes' ability to penetrate the intestinal barrier. As a result of the increased diffusion of microorganisms, the immune system is activated, and can trigger an autoimmune reaction. All of these consequences of low vitamin $\mathrm{D}$ levels in plasma contribute directly or indirectly to the intensification of autoimmune processes, and the occurrence of vitamin D-related diseases [59].

\section{AUTOIMMUNE DISEASES}

A meta-analysis by Skaaba et al. [55] reviewed studies on patients with selected autoimmune diseases, including: psoriasis, autoimmune thyroid disorders (AITD), type 1 diabetes, multiple sclerosis, iritis, IBD, and RA. The meta-analysis assessed the plasma vitamin $\mathrm{D}$ levels in patients with these diseases. In each of these disease entities, the exact relationship with the vitamin D levels was different and resulted from the vitamin effect on the pathophysiological processes characteristic of a given disease entity. In the case of autoimmune diseases of the thyroid gland, a relationship was observed between the vitamin D levels and the development of diseases. However, in the case of IBDs and RA, the conclusions are ambiguous. The authors of this meta-analysis confirmed a significantly lower incidence of autoimmune diseases in the case of higher vitamin D levels in the blood of the tested subjects, while vitamin D deficiencies were associated with an increased risk of developing these diseases in the future.

\section{Autoimmune diseases of the thyroid gland}

Autoimmune diseases of the thyroid gland include, among others, chronic lymphocytic thyroiditis (for example, Hashimoto's thyroiditis (HT)), and Graves' disease. The prevalence of these diseases is $5 \%$ of the overall population, and the observed vitamin D deficiency in $70 \%$ of patients those autoimmune diseases. The autoimmune process in the thyroid gland usually takes the form of lymphocytic infiltrates with the presence of antibodies against thyroid cells, for example antibodies against thyroglobulin (anti$\mathrm{Tg}$ ), thyroid stimulating hormone (TSH) receptor (anti-Tr) and thyroid peroxidase (anti-TPO) [6]. There are also disturbances in the production of thyroid hormones. In the case of autoimmune thyroid diseases, increased serum TSH levels and decreased levels of triiodothyronine (T3) and tyrosine (T4) are observed. TSH is secreted by the pituitary gland, and coordinates secretion of hormones by the thyroid gland [34].

Vitamin D plays a significant role in the pathogenesis of these diseases through anti-inflammatory activity. For example, in HT, increased levels of anti-TPO and anti-Tg have been observed in the blood. In addition, there is a characteristic presence of thyroid lymphocytic infiltrates caused by cytokines synthesized by Th1 lymphocytes (IL-2, IFN- $\gamma$, TNF- $\alpha$ ). In the case of Graves' disease, cytokines are synthesized by Th2 lymphocytes (IL-1, IL-5, IL-10), which stimulate the secretion of anti-Tr [6].

The mechanism of vitamin $\mathrm{D}$ reduces the proliferation of B lymphocytes in plasma cells, which reduces the amount of secreted antibodies affecting the development of autoimmune reactions within the 
thyroid gland. In addition, the mechanism of vitamin $\mathrm{D}$ is associated with a reduction in the secretion of proinflammatory cytokines by Thl lymphocytes, and an increase in the secretion of specific anti-inflammatory cytokines by $\mathrm{Th} 2[6,41]$.

\section{Hashimoto's disease}

A relationship between the concentrations of vitamin D, TSH and anti-TPO was observed in the course of Hashimoto's disease. In patients with a vitamin D deficiency there is a much higher concentration of TSH and anti-TPO in the blood [8]. Due to limited data on the impact of vitamin D supplementation on the development of AITD, Chaudhary et al. [11] assessed the effectiveness of vitamin $\mathrm{D}$ supplementation in patients with newly diagnosed AITD. The subjects were divided into a control group $(\mathrm{n}=51)$, and a study group $(\mathrm{n}=51)$. The participants in the study group received cholecalciferol at a dose of 60,000 IU per week for a period of 8 weeks. The authors of this study observed a reduction in anti-TPO values compared to the baseline concentration in the study group. In an unhealthy group with a baseline serum TSH $\leq 10$ mIU, a much greater decrease in anti-TPO values was observed. According to Chaudhary et al. [11], the above dependence was caused by the severity of the disease. In the case of patients in the early stages of AITD, whose serum TSH concentration does not exceed $10 \mathrm{mUI}$, vitamin D3 supplementation will be the most beneficial.

El Rawi et al. [18] assessed the relationship between abnormal vitamin $\mathrm{D}$ levels in the plasma and the incidence of hypothyroidism in the course of Hashimoto's disease. As part of their study, a clinical picture of the thyroid gland and the concentration of triiodothyronine, thyroxine, TSH, anti-TPO, and anti-Tg were assessed. The participants were divided into a study group $(\mathrm{n}=35)$, consisting of patients with hypothyroidism, and a control group $(\mathrm{n}=35)$, composed of healthy people. The scientists found a relationship between vitamin $\mathrm{D}$ levels and the occurrence of hypothyroidism. The authors of this study estimated that higher plasma vitamin D levels were associated with lower anti-TPO and anti-Tg secretion. However, no correlation was found between the blood vitamin D and TSH levels. Low vitamin D levels were associated with a lower thyroid weight and a larger area of nodularity. T3 and T4 hormones levels were higher with the increase of vitamin D levels in the blood.

Kim et al. [38] also assessed the relationship of vitamin D levels in the blood and AITD. The study group involved the Korean population $(n=4181)$ and was based on a comparative analysis of patient study results. The authors found no correlation between vitamin D levels and the incidence of autoimmune hypothyroidism.
Simsek et al. [54] assessed whether vitamin D supplementation reduced the severity of autoimmune diseases of the thyroid gland. The group that qualified for the study consisted of people with diagnosed AITD, who were additionally diagnosed with a vitamin D deficiency $(<20 \mathrm{ng} / \mathrm{mL})$. The subjects were randomly divided into a study group $(n=46)$, which received a daily dose of 1,000 IU of vitamin D for a period of 1 month, and a control group $(n=36)$, which did not receive supplementation. In the patients receiving vitamin D, lower levels of anti-TPO and anti-Tg were observed as compared to the control group. The authors did not observe any significant changes in TSH, T3, T4 concentrations during the study. It has been suggested that vitamin D deficiency is associated with the pathogenesis process of autoimmune thyroid disease.

\section{Inflammatory bowel disease}

Inflammatory bowel diseases (IBDs) are autoimmune diseases caused by a genetic predisposition that affects the immune mechanisms of the intestinal barrier and the microbiome. Inflammatory bowel diseases include Crohn's disease (CD) and ulcerative colitis (UC). The diseases are differentiated according to the area of the gastrointestinal tract in which the inflammatory changes are observed. In the case of $\mathrm{CD}$, the inflammatory foci occur in all parts of the digestive system - the mouth, throat, esophagus, stomach, small intestine and large intestine. Most often, though, CD occurs in the final section of the small intestine. In $\mathrm{CD}$, inflammation in all layers of the intestinal wall is observed. In contrast, UC affects only the mucosa of the large intestine. The course and severity of the diseases are associated with gastrointestinal symptoms. The most common symptoms of UC are diarrhea, enddigestive bleeding, weight loss, weakness, and fever. In the case of $\mathrm{CD}$, symptoms include fever, weakness, weight loss, diarrhea, vomiting and ulceration. The symptoms are related to the part of the digestive system that is affected by the inflammation, and depend on the intensity of the inflammation $[4,43]$.

Mechie et al. [43] assessed whether vitamin D levels in the plasma had an effect on the activity of IBD (UC, CD). The study group consisted of 233 patients with IBD. Vitamin D deficiency was diagnosed in $54 \%$ of patients. Lower vitamin D levels $(<20 \mathrm{ng} /$ $\mathrm{mL}$ ) were observed more frequently in patients with UC compared to patients with $\mathrm{CD}$. The authors of the study showed a relationship between higher plasma vitamin $\mathrm{D}$ levels and remission in those IBDs. The scientists presented a disease activity scale depending on vitamin $\mathrm{D}$ concentration. In $\mathrm{CD}$, the value $>19 \mathrm{ng} /$ $\mathrm{mL} 25(\mathrm{OH}) \mathrm{D}$ was assessed by the authors as a clinical remission, and $>26 \mathrm{ng} / \mathrm{mL}$ as deep remission. In UC, concentration of $25(\mathrm{OH}) \mathrm{D}>32 \mathrm{ng} / \mathrm{mL}$ was defined as a state of clinical remission. The authors of this study 
speculated that when disease exacerbated, plasma vitamin D levels fell, reaching the levels seen with severe vitamin $\mathrm{D}$ deficiencies. In case of remission, an increase in vitamin D levels in the blood is observed.

Janssen et al. [32] assessed the effect of vitamin D levels on IBD activity and plasma vitamin D levels depending on the season of the year. Their study included 384 patients enrolled in the first blood vitamin D measurement, and 208 enrolled in the second measurement after 24 months. The scientists found vitamin $\mathrm{D}$ deficiencies in $63 \%$ of $\mathrm{CD}$ patients, and $7 \%$ in patients with UC. Additionally, differences in plasma vitamin D levels depending on the season were determined, with a deficiency associated with the spring and winter seasons. The reduced activity of IBD was associated with an increase in plasma vitamin D levels in $\mathrm{CD}$. The scientists observed lower plasma vitamin D levels when the disease was active, compared to when it was in its remission state.

Martin et al. [42] assessed the effectiveness of high-dose supplementation of vitamin D in children diagnosed with IBD. The study group consisted of children $(n=23)$ aged 3-16 who were administered vitamin D in a single dose of 100,000-800,000 IU. The appropriate dose was selected depending on the patient's body weight. Martin et al. [42] observed an increase in blood vitamin D levels in all subjects within a period of 1-2 months after its administration. The scientists noted decreased value in the inflammatory markers: the number of platelets, C-reactive protein (CRP), erythrocyte sedimentation rate (ESR), 3 months after the vitamin D's administration and a decrease in disease activity.

Jørgensen et al. [35] conducted a randomized, double-blind study on the effect of vitamin D supplementation on the course and severity of symptoms in patients with $\mathrm{CD}$. The subjects were randomized into 2 groups. The study group $(n=46)$ took a daily dose of $1,200 \mathrm{IU}$ of vitamin D for a period of 12 months, and the control group $(\mathrm{n}=48)$ took a placebo. The scientists observed a significant increase in the blood vitamin D levels in the study group, and a reduction in relapses from $29 \%$ to $13 \%$. The authors of the study suggest introducing a safe supplementation dose to supplement the IBD treatment.

In the studies conducted so far, the adverse effect of vitamin D deficiency on the course and intensity of symptoms in IBD was observed. There is a need to conduct clinical trials on the impact of supplementation with specific doses of vitamin D on the condition of IBD patients, and to develop specific guidelines on supplementation $[35,51,58,59]$.

\section{Rheumatoid arthritis}

Rheumatoid arthritis is an autoimmune disease that affects the cells of the joints. It is associated with chronic inflammation in the joints. RA occurs in $0.3-1 \%$ of the overall population, more often in women. The exact pathogenesis of the disease is not known, however, environmental factors and genetic predisposition are believed to be the causes. The clinical picture of the disease is the presence of synovial infiltration caused by the immune system cells, such as macrophages, $\mathrm{T}$ cells, B cells, dendritic cells and neutrophils. The infiltrations are associated with damage to joint tissue, and pain. The main symptoms include severe pain in the symmetrical joints, most often in the arms and legs, and joint stiffness. Additionally, symptoms of low-grade fever, or fever, muscle pain, and fatigue are observed. Inflammatory changes also occur in the tendons, ligaments and synovial bursae. The occurrence of inflammation within the above-mentioned elements causes the damage and disappearance of the function of the locomotor apparatus. The inflammation caused by RA is, among other things, caused by IL-17 and interleukin 23 (IL-23). Rheumatoid arthritis markers are anti-citrullinated peptide antibodies (ACPA) in plasma, also known as anti-CPP, and the presence of rheumatoid factor (RF) in the serum. Antibodies are not present in all patients, but their occurrence is associated with a more severe course of the disease. In the case of RA, increased erythrocyte sedimentation rate (ESR) and CRP are also observed [19,29].

Hong et al. [29] assessed the relationship between serum $25(\mathrm{OH}) \mathrm{D}$ concentration and pro-inflammatory cytokine activity in the course of RA. A total of 130 patients with RA and 80 people constituting a control group were enrolled in the study. A vitamin D deficiency was found in $98.5 \%$ of RA subjects. Hong et al. [29] found that the disease was more active, with more severe pain symptoms, in RA patients with lower plasma vitamin $\mathrm{D}$ levels. The researchers also observed an inverse relationship between vitamin D levels and the synthesis of IL-17 and IL-23. The increase in interleukin levels was observed with exacerbation of the disease. The authors speculate that vitamin D deficiency can influence the pathogenesis of RA.

Yang et al. [60] analyzed the relationship between the vitamin D levels in the blood and the risk of RA's recurrence. The study included 377 participants who were divided into two groups according to their plasma vitamin D concentration. The group with normal vitamin $D$ levels $(n=168)$ was separated from the blood vitamin $\mathrm{D}$ deficiency group. The group with inadequate concentration of vitamin D was randomly divided into two groups. In the first group $(n=84)$, vitamin $\mathrm{D}$ was administered in the form of alfa-calcidol in a twicedaily dose of $0.25 \mu \mathrm{g}$ for 24 months. The second group $(n=88)$ did not receive vitamin D supplementation. Yang et al. [60] found a relationship, and concluded that as vitamin D levels in the body decreased, the risk of the disease's recurrence increased. The relapse rate 
was $16.7 \%$ in the patients with normal serum vitamin D levels, $19 \%$ in the patients with hypovitaminosis receiving supplementation, and $29.5 \%$ in the patients not receiving supplementation.

Di Franco et al. [15] assessed the effect of serum vitamin $\mathrm{D}$ levels on the diagnosis and progression of the disease in patients with RA. Observation of the study group ( $\mathrm{n}=37$ ) lasted 12 months. The pharmacological treatment of RA included corticosteroids (prednisone of up to $10 \mathrm{mg} /$ day), and methotrexate (MTX) at a dose of $7.5-15 \mathrm{mg} /$ week. The authors showed that RA patients with hypovitaminosis occurring from the early stages of the disease are more prone to acute disease, and less prone to treatment and remissions.

On the basis of observations of 1,191 RA patients, Rossini et al. [52] estimated that the occurrence of deficiencies in patients is common and reaches 40$50 \%$. In addition, the authors of this study showed that as plasma vitamin D levels increased, disease activity and physical disability decreased.

Khajoei et al. [37] assessed the effect of the concentration of vitamin D, adiponectin, copper and zinc in the plasma on RA activity. The study group consisted of people diagnosed with RA $(n=90)$, and a control group $(n=30)$ composed of healthy people characterized by a lack of elevated levels of IgM rheumatoid factor and plasma anti-CCPs. The condition for participation in the study was the patients' declaration that they had not supplemented vitamin $\mathrm{D}$ and calcium during the last 2 months. Disease activity was assessed using the Disease Activity Score 28-joint count (DAS28). The study group continued pharmacological therapy of RA with the following drugs: MTX 7.5-25 mg weekly; sulfasalazine 500$3000 \mathrm{mg}$ daily, and hydroxychloroquine $200 \mathrm{mg}$ daily. Participants from the study group were divided according to the disease's clinical status: remission $(n=22)$; mild disease activity $(n=20)$; moderate disease activity $(n=32)$, and severe disease $(n=16)$. When assessing the concentration of copper and zinc in the serum, the authors of this study did not notice any significant differences. The adiponectin levels increased with increasing disease activity. Vitamin D concentration averaged $35 \mathrm{ng} / \mathrm{mL}$ in the control group. In the study group, in disease remission, the vitamin $\mathrm{D}$ levels were $32.5 \mathrm{ng} / \mathrm{mL}$; in mild disease the level was $19 \mathrm{ng} / \mathrm{mL}$; in moderate disease the level was $20 \mathrm{ng} / \mathrm{mL}$, and $14.5 \mathrm{ng} / \mathrm{mL}$ in severe disease. The authors of this study showed a decrease in plasma vitamin $\mathrm{D}$ levels in patients with mild, moderate and severe disease. The differences between the groups were slight.

Herly et al. [27] assessed the effect of the concentration of active vitamin D metabolites in plasma on the activity of RA. The study group $(n=160)$ consisted of people with RA who had never been treated and had not received vitamin $\mathrm{D}$ and calcium supplementation. The concentration of vitamin D metabolites $\left(25 \mathrm{OHD}_{2}, \quad 25 \mathrm{OHD}_{3}\right.$ and $\left.1.25(\mathrm{OH})_{2} \mathrm{D}\right)$ was assessed and the total vitamin D levels were calculated as the sum of $25 \mathrm{OHD}_{2}$ and $25 \mathrm{OHD}_{3}$. Each study participant underwent tests in which disease activity was assessed on the basis of, among other things, DAS28-CRP and CRP protein concentration, anti-CCP, and RF. Herly et al. [27] showed low total vitamin D levels in $42 \%$ of the subjects $(<50 \mathrm{nmol} / \mathrm{L})$. Low $1.25(\mathrm{OH})_{2}$ concentration was associated with low total vitamin D levels. However, the authors of the study observed a low percentage of people with low $1.25(\mathrm{OH})_{2}$ levels, and a relationship between the blood $1.25(\mathrm{OH})_{2}$ levels with disease activity (DAS28-CRP), and the CRP levels. Both parameters showed a downward trend with an increase in the concentration of $1.25(\mathrm{OH})_{2}$. Herly et al. also showed a significant relationship between the $1.25(\mathrm{OH})_{2} \mathrm{D}$ and the concentration of anti-CCP. As the concentration of $1.25(\mathrm{OH}) 2 \mathrm{D}$ increased, the concentration of anti-CCP decreased.

\section{CONCLUSIONS}

Vitamin D deficiencies in the body exacerbate inflammation-promoting responses and disturb the balance of anti-inflammatory activity in the immune system. This increases the chances of inflammation, and therefore, autoimmune diseases. The analyzed literature shows that it is important to maintain the proper concentration of vitamin D in the plasma to reduce the risk of developing autoimmune diseases. This conclusion was demonstrated by the authors of the studies analyzed herein, in relation to autoimmune thyroid disease, IBD and RA. Vitamin D levels influenced the course of these diseases, the severity of the symptoms, and the frequency of relapses. In the case of AITD and RA, the authors of the studies demonstrated the effect of low plasma vitamin D levels on the increase in the amount of secreted antibodies, which in turn determined disease activity. Low vitamin D levels were also associated with a higher incidence of relapses in IBD and RA. The relationships between lower vitamin $\mathrm{D}$ levels and a greater degree of damage and nodular changes in the thyroid gland in AITD, as well as a greater degree of motor disability in RA, were all shown. The studies' authors also observed an increase in the secretion of IL-17 and IL-23, anti-CCP, and an increased risk of relapse in the presence of lower blood vitamin D levels in RA. The studies showed the positive effect of vitamin D supplementation in IBD patients. This beneficial effect was associated with the reduction of inflammatory markers such as: platelet count, CRP, and ESR. The timely correction of vitamin $\mathrm{D}$ deficiencies was associated with a better response to pharmacological treatment and a reduction in symptoms 
in RA patients. The authors of the analyzed studies emphasize the importance of maintaining correct blood vitamin $\mathrm{D}$ levels and preventing deficiencies that may worsen the symptoms of the diseases, or cause development of an autoimmune disease. In the case of insufficient amounts of vitamin D supplied to the body, supplementation is recommended. The supplementation should be consulted with a physician and selected on an individual basis.

\section{Conflict of interest}

The authors declare no conflict of interest.

\section{REFERENCES}

1. Andrukhova O., Slavic S., Zeitz U., Riesen S. C., Heppelmann M. S., Ambrisko T. D., Markovic M., Kuebler W. M., Erben R.E.: Vitamin D is a regulator of endothelial nitric oxide synthase and arterial stiffness in mice. Mol Endocrinol 2014; 28(1):53-64. doi: 10.1210/ me.2013-1252.

2. Balanowski M.: Osteoporoza [Osteoporosis]. In: Bolanowski M., Kuliczkowska-Ptaska J. eds. Endokrynologia w praktyce klinicznej. Wrocław. Wrocław Medical University 2019 (in Polish).

3. Bańkowski E.: Witaminy i składniki mineralne [Vitamin and mineral supplements]. In: Biochemia. Wrocław. Edra Urban \& Partner, 2014 (in Polish).

4. Bartnik W., Ciećkiewicz J., Januszewicz.: Choroby jelita grubego [Large intestine disease]. In: Gajewski P., Szczeklik A. Interna Szczeklika. Kraków. Medycyna Praktyczna, 2017 (in Polish).

5. Bashir M., Prietl B., Tauschmann M., Mautner S. I., Kump P.K. , Treiber G., Wurm P., Gorkiewicz G., Högenauer C., Pieber T. R.: Effects of high doses of vitamin D3 on mucosa-associated gut microbiome vary between regions of the human gastrointestinal tract. Eur J Nutr 2016; 55(4):1479-89. doi: 10.1007/s00394-0150966-2.

6. Bellan M., Andreoli L., Mele C., Sainaghi P. P., Rigamonti C., Piantoni S., De Benedittis C., Aimaretti G., Pirisi M., Marzullo P.: Pathophysiological role and therapeutic implications of vitamin D in autoimmunity: Focus on chronic autoimmune diseases. Nutrients 2020; 12(3): 789. doi: 10.3390/nu12030789.

7. Berridge M. J.: Vitamin D signaling in health and disease. Biochem Biophys Res Commun 2015; 24:460(1):53-71. doi: 10.1016/j.bbrc.2015.01.008.

8. Bizzaro G., Shoenfeld Y.: Vitamin D and autoimmune thyroid diseases: facts and unresolved questions. Immunol Res 2015; 61(1-2):46-52. doi: 10.1007/s12026014-8579-z.

9. Cantorna M., Snyder L., Lin J.: Vitamin D and $1,25(\mathrm{OH})_{2} \mathrm{D}$ regulation of T cells. Nutrients 2015; 7(4): 3011-3021.

10. Charoenngam N., Shirvani A., Holick M. F.: Vitamin D for skeletal and non-skeletal health: What we should know. J Clin Orthop Trauma 2019;10(6):1082-1093. doi: 10.1016/j.jcot.2019.07.004.10, 1082-1093.
11. Chaudhary S., Dutta D., Kumar M,. Saha S., Mondal S. A., Kumar A., Mukhopadhyay S.: Vitamin D supplementation reduces thyroid peroxidase antibody levels in patients with autoimmune thyroid disease: An open-labeled randomized controlled trial. Indian J Endocrinol Metab 2016; 20(3):391-8. doi: 10.4103/22308210.179997.

12.Chen S., Sims G. P., Chen X., , Gu Y., Chen S., Lipsky P. E.: Modulatory effects of 1,25-dihydroxyvitamin $\mathrm{D}_{3}$ on human $\mathrm{B}$ cell differentiation. J Immunol 2007; 179(3):1634-47. doi: 10.4049/jimmunol.179.3.1634.

13. Chetcuti Zammit S., Ellul P., Girardin G., Valpiani D., Nielsen K. R., Olsen J., Goldis A., Lazar D., Shonová O, Nováková M, Sebastian S., Whitehead E., Carmona A., Martinez-Cadilla J., Dahlerup J. F., Kievit A L. H., Thorsgaard N., Katsanos K.H., Christodoulou D. K., Magro F., Salupere R., Pedersen N, Kjeldsen J, Carlsen K, Ioannis K., Bergemalm D., Halfvarson J., Duricova D., Bortlik M., Collin P., Oksanen P., Kiudelis G., Kupcinskas L., Kudsk K., Andersen V., O'Morain C., Bailey Y., Doron S., Shmuel O., Almer S., Arebi N., Misra R., Čuković-Čavka S., Brinar M., Munkholm P., Vegh Z., Burisch J.: Vitamin D deficiency in a European inflammatory bowel disease inception cohort: an EpiIBD study. Eur J Gastroenterol Hepatol 2018; 30(11):12971303. doi: 10.1097/MEG.0000000000001238.

14.Dankers W., Colin E. M., van Hamburg J. P., Luberrts $J .:$ Vitamin D in autoimmunity: Molecular mechanisms and therapeutic potential. Front Immunol 2017, 7, doi: 10.3389/fimmu.2016.00697.

15.Di Franco M., Barchetta I., Iannuccelli C., Gerardi M. C., Frisenda S., Ceccarelli F., Valesini G., Cavallo $M$. G.: Hypovitaminosis D in recent onset rheumatoid arthritis is predictive of reduced response to treatment and increased disease activity: a 12 month follow-up study. BMC Musculoskelet Disord 2015; 16: 53. doi: 10.1186/s12891-015-0505-6.

16.Edfeldt K., Liu P. T., Chun R., Fabri M., Schenk M., Wheelwright M., Keegan C., Krutzik S. R., Adams J. S., Hewison M., Modlin R. L.: Affiliations expand T-cell cytokines differentially control human monocyte antimicrobial responses by regulating vitamin D metabolism. Proc Natl Acad Sci USA 2010; 107(52):22593-8. doi: 10.1073/pnas.1011624108.

17. EFSA NDA Panel (EFSA panel on dietetic products, nutrition and allergies), scientific opinion on dietary reference values for vitamin D. Available https://efsa. onlinelibrary.wiley.com/doi/10.2903/j.efsa.2016.4547 7 (Accessed 11.2019).

18. El Rawi H. A., Ghanem N. S., El Sayed N. M., Ali H. M., Rashed L. A., Mansour M. M.: Study of vitamin $\mathrm{d}$ level and vitamin $\mathrm{D}$ receptor polymorphism in hypothyroid egyptian patients. J Thyroid Res 2019; 26. doi: 10.1155/2019/3583250.

19. Filipowicz-Sosnowska A.: Choroby układowe tkanki łącznej [Connective tissue diseases]. In: Gajewski P., Szczeklik A. i wsp.: Interna Szczeklika. Kraków. Medycyna Praktyczna, 2017 (in Polish).

20.Fisher S. A., Rahimzadeh M., Brierley C., Gration B., Doree C., Kimber C. E., Cajide A. P., Lamikanra A. 
A., Roberts D .J.: The role of vitamin D in increasing circulating $\mathrm{T}$ regulatory cell numbers and modulating $\mathrm{T}$ regulatory cell phenotypes in patients with inflammatory disease or in healthy volunteers: A systematic review. PLoS One 2019; 14. doi: 10.1371/journal.pone.0222313.

21. Girgis C. M., Clifton-Bligh R. J., Hamrick M. W., Holick M. F., Gunton J. E.: The roles of vitamin D in skeletal muscle: form function and metabolism. Endocr. Rev 2013; 34(1):33-83. doi: 10.1210/er.2012-1012.

22. Gombart A. E., Borregaard N., Koeffler H.F.: Human cathelicidin antimicrobial peptide (CAMP) gene is a direct target of the vitamin $\mathrm{D}$ receptor and is strongly up-regulated in myeloid cells by 1,25-dihydroxyvitamin D3. FASEB J 2005; 19(9):1067-77. doi: 10.1096/fj.04$3284 \mathrm{com}$.

23. Gorman S., Judge M.A., Hart P.H.: Topical 1,25-dihydroxyvitamin D3 subverts the priming ability of draining lymph node dendritic cells. Immunology 2010; 131(3):415-25. doi: 10.1111/j.1365-2567.2010.03315.x.

24.Griffin M. D., Lutz W., Phan V. A., Bachman L. A., McKean D. J., Kumar R.: Dendritic cell modulation by 1alpha,25 dihydroxyvitamin D3 and its analogs: a vitamin D receptor-dependent pathway that promotes a persistent state of immaturity in vitro and in vivo. Proc Natl Acad Sci U S A 2001; 98(12):6800-5. doi: 10.1073/ pnas.121172198.

25. Grygiel-Górniak B., Puszczewicz M.: Witamina D nowe spojrzenie $\mathrm{w}$ medycynie i reumatologii [Vitamin $\mathrm{D}$ - new perspective in medicine and rheumatology]. Postepy Hig Med Dosw 2014; 2014; 68: 359-368 (in Polish).

26.Harry R. A., Anderson A. E., Isaacs J. D., Hilkens C. $M$. $U .:$ Generation and characterisation of therapeutic tolerogenic dendritic cells for rheumatoid arthritis. Ann Rheum Dis 2010; 69(11):2042-50. doi: 10.1136/ ard.2009.126383.

27. Herly M., Stengaard-Pedersen K., Vestergaard P., Østergaard M., Junker P., Hetland M. L., HørslevPetersen K., Ellingsen T.: The D-vitamin metabolite $1,25(\mathrm{OH})_{2} \mathrm{D}$ in serum is associated with disease activity and anti-citrullinated protein antibodies in active and treatment naïve, early rheumatoid arthritis patients. Scand J Immunol 2018; 88(3). doi: 10.1111 / sji.12704.

28. Hewison M.: An update on vitamin D and human immunity. Clin Endocrinol (Oxf) 2012 ;76(3):315-25. doi: 10.1111/j.1365-2265.2011.04261.x.

29.Hong Q., Xu J., Xu S. Lian L., Zhang M., Ding C.: Associations between serum 25-hydroxyvitamin D and disease activity, inflammatory cytokines and bone loss in patients with rheumatoid arthritis. Rheumatology (Oxford) 2014;53(11):1994-2001. doi: 10.1093/ rheumatology/keu173.

30.Hu J., Wan Y.: Tolerogenic dendritic cells and their potential applications. Immunology 2011; 132(3): 307314. doi: 10.1111/j.1365-2567.2010.03396.x.

31. Jakóbsiak M.: Główne komponenty i zasadnicze cechy odpowiedzi immunologicznej [Main components and fundamental features of the immune response]. In: Losek W., Gołab J., Jakubiak M. Stokłosa T.: Immunologia.
Warszawa. Wydawnictwo naukowe PWN 2017 (in Polish).

32.Janssen C. E., Globig A. M., Busse Grawitz A., Bettinger $D$., Hasselblatt P.: Seasonal variability of vitamin D status in patients with inflammatory bowel disease A retrospective cohort study. PLoS One 2019; 14(5). doi: 10.1371/journal.pone.0217238.

33.Jarosz M., Stoś K., Przygoda B., Matczuk E., Stolińska - Fiedorowicz H., Kłys W.: Witaminy [Vitamin]. In: Jarosz M., Buthak - Jachymczyk B.: Normy żywienia dla populacji Polski [Nutritional standards for the population of Poland]. Warszawa. IŻŻ 2017 (in Polish).

34.Jarząb B., Lewiński A., Płaczkiewicz-Jankowska E.: Choroby tarczycy [Thyroid disease]. In: Gajewski P., Szczeklik A.: Interna Szczeklika., Kraków. Medycyna Praktyczna, 2017 (in Polish).

35. Jørgensen S. P., Agnholt J., Glerup H., Lyhne S., Villadsen G. E., Hvas C. L., Bartels L. E., Kelsen J., Christensen L. A., Dahlerup J. F.: Clinical trial: vitamin $\mathrm{D}_{3}$ treatment in Crohn's disease - a randomized double-blind placebocontrolled study. Aliment Pharmacol Ther 2010; 32(3):377-83. doi: 10.1111/j.1365-2036.2010.04355.x.

36.Joshi S., Pantalena L., Liu X. K., Gaffen S. L., Liu H., Rohowsky-Kochan C., Ichiyama K., Yoshimura A., Steinman L., Christakos S., Youssef S.: 1,25dihydroxyvitamin $\mathrm{D}_{3}$ ameliorates Th17 autoimmunity via transcriptional modulation of interleukin-17A. Mol Cel Biol 2011; 31(17): 3653-3669. doi: 10.1128/ MCB.05020-11.

37. Khajoei S., Hassaninevisi M., Kianmehr N., Seif F., Khoshmirsafa M., Shekarabi M., Samei A., Haghighi A.: Serum levels of adiponectin and vitamin D correlate with activity of rheumatoid arthritis. Mol Biol Rep 2019; 46(2):2505-2512. doi: 10.1007/s11033-019-04682-1.

38. Kim M., Song E., Oh H., Park P., Kwon H., Ji Jeon M., Kim W., Kim W. Kee Shong Y.,1, Yong Kim T.: Vitamin D deficiency affects thyroid autoimmunity and dysfunction in iodine-replete area: Korea national health and nutrition examination survey. Endocrine 2017; 58(2):332-339. doi: 10.1007/s12020-017-1425-z.

39. Kokot F., Franek E.: Zaburzenia gospodarki wapniowofosforanowej i witaminy D [Disorders of calcium, phosphate and vitamin D metabolism]. In: Gajewski P., Szczeklik A. eds. Interna Szczeklika., Kraków. Medycyna Praktyczna 2017 (in Polish).

40.Kongsbak M., Von Essen M. E., Boding L., Levring T. B., Schjerling P., Lauritsen J. P. H., Woetmann A., Ødum N., Bonefeld C. M., Geisler C.: Vitamin D Up-Regulates the Vitamin D Receptor by Protecting It from Proteasomal Degradation in Human CD4+ T Cells. PLoS One 2014: 9. doi: 10.1371/journal.pone.0096695.

41. Ma J., Wu D., Li C., Fan C., Chao N., Liu J., Li J., Wang $R$., Miao W., Guan H., Shan Z., Teng W.: Lower serum 25-hydroxyvitamin D level is associated with 3 types of autoimmune thyroid diseases. Medicine (Baltimore) 2015; 94(39). doi: 10.1097/MD.0000000000001639.

42.Martin N. G., Rigterink T., Adamji M., Wall C. L., Day $A$. S.: Single high-dose oral vitamin $\mathrm{D}_{3}$ treatment in New Zealand children with inflammatory bowel 
disease. Transl Pediatr 2019; 8(1): 35-41.doi: 10.21037/ tp.2018.11.01.

43. Mechie N. C., Mavropoulou E., Ellenrieder V., Petzold G., Kunsch S., Neesse, A., Amanzada A.: Serum vitamin $\mathrm{D}$ but not zinc levels are associated with different disease activity status in patients with inflammatory bowel disease. Medicine (Baltimore) 2019; 98(15). doi: 10.1097/MD.0000000000015172.

44.Murray P. J., Wynn T. A.: Protective and pathogenic functions of macrophage subsets. Nat Rev Immunol 2011; 11(11): 723-737. doi: 10.1038/nri3073.

45. Myszka M., Klinger M.: The immunomodulatory role of Vitamin D. Postepy Hig Med Dosw 2014; 68: 865-878. doi: 10.5604/17322693.1110168.

46. Norman $A$. $W$.: The history of the discovery of vitamin D and its daughter steroid hormone. Ann Nutr Metab 2012; 61(3):199-206. doi: 10.1159/000343104.

47. Pérez-Hernández N., Aptilon-Duque G., NostrozaHernández M., Vargas-Alarcón G., Rodríguez-Pérez J. M., Blachman-Braun R.:Vitamin D and its effects on cardiovascular diseases: a comprehensive review. Korean J Intern Med 2016; 31(6): 1018-1029. doi: 10.3904/kjim.2015.224.

48.Pike J. W., Meyer M. B., Seong-Min L. M., Benkusky N.A : The vitamin D receptor: contemporary genomic approaches reveal new basic and translational insights. J Clin Invest 2017; 127(4): 1146-1154. doi: 10.1172/ JCI88887.

49. Prentice R. L., Pettinger M. B., Jackson R. D., Wactawski-Wende J., Lacroix A. Z., Anderson G. L., Chlebowski R. T., Manson J. E., Van Horn L., Vitolins M. Z., Datta M., Leblanc E. S., Cauley J. A., Rossouw J. E.: Health risks and benefits from calcium and vitamin D supplementation: Women's Health Initiative clinical trial and cohort study. Osteoporos Int 2013; 24(2): 567-580. doi: 10.1007/s00198-012-2224-2.

50.Prietl B., Treiber G., Mader J. K., Hoeller E., Wolf M., Pilz S., Graninger W. B., Obermayer-Pietsch B. M., Pieber T. R.: High-dose cholecalciferol supplementation significantly increases peripheral CD $4^{+}$Tregs in healthy adults without negatively affecting the frequency of other immune cells. Eur J Nutr 2014; 53(3):751-9. doi: 10.1007/s00394-013-0579-6.

51. Prietl B., Treiber G., Piebe T., Amrein K.: Vitamin D and immune function. Nutrients 2013; 5(7): 2502-2521. https://doi.org/10.3390/nu5072502.

52. Rossini M., Maddali Bongi S., La Montagna G., Minisola G., Malavolta N., Bernini L., Cacace E., Sinigaglia L., Di Munno O., Adami S.: Vitamin D deficiency in rheumatoid arthritis: prevalence, determinants and associations with disease activity and disability. Arthritis Res Ther 2010; 12(6). doi: 10.1186/ar3195.

53. Roth D. E., Abrams S. A., Aloia J., Bergeron G., Bourassa M. W., Brown K. H., Calvo M. S., Cashman K.
D., Combs G., De-Regil L. M., Jefferds M. E., Jones K.S., Kapner H., Martineau A. R., Neufeld l. M., Schleicher R. L., Thacher T. D.,. Whiting S.J.: Global prevalence and disease burden of vitamin $\mathrm{D}$ deficiency: a roadmap for action in low- and middle-income countries. Ann NY Acad Sci 2018 ; 1430(1): 44-79. doi: 10.1111/nyas.13968.

54.Simsek Y., Cakir I., Yetmis M., Dizdar O. S., Baspinar O., Gokay F.: Effects of Vitamin D treatment on thyroid autoimmunity. J Res Med Sci 2016; 21:85. doi: 10.4103/1735-1995.192501.

55. Skaaby T., Nystrup Husemoen L. L., Heinsbcek Thuesen B.H., Linneberg A.: Prospective population-based study of the association between vitamin D status and incidence of autoimmune disease. Endocrine 2015; 50(1):231-8. doi: 10.1007/s12020-015-0547-4.

56. The Human Protein Atlas, Available https://www. proteinatlas.org/ENSG00000111424-VDR/tissue (Accessed 30.04.2020).

57. Wang T., Dabbas B., Laperriere D., Bitton A. J., Soualhine H., Tavera-Mendoza L. E., Dionne S., Servant M.J., Bitton A., Seidman E.G., Mader S., Behr M. A., White J. H.: Direct and indirect induction by 1,25-dihydroxyvitamin D3 of the NOD2/CARD15defensin beta2 innate immune pathway defective in Crohn disease. J Biol Chem 2010; 285(4):2227-31. doi: 10.1074/jbc.C109.071225.

58. Wu S., ZhangY., Lu R. Xia Y., Zhou D., Petrof E., Claud E. C., Chen D., Chang E. B. Carmeliet G., Sun J.: Intestinal epithelial vitamin $\mathrm{D}$ receptor deletion leads to defective autophagyin colitis. Gut 2015; 64(7): 10821094. doi:10.1136/gutjnl-2014-307436.

59. Yamamoto E. A., Jørgensen T. N.: Relationships between vitamin $\mathrm{D}$, gut microbiome, and systemic autoimmunity. Front Immunol. 2019, 10, doi: 10.3389/fimmu.2019.03141.

60. Yang J., Liu L., Zhang Q., Li M., Wang J.: Effect of vitamin $\mathrm{D}$ on the recurrence rate of rheumatoid arthritis. Exp Ther Med 2015; 10(5): 1812-1816. doi: 10.3892/ etm.2015.2747.

61. Zhao H., Zhang H., Wu H., Li H., Liu L., Guo J., Li H., Shih D. Q., Zhang X.: Protective role of $1,25(\mathrm{OH})_{2}$ vitamin $\mathrm{D}_{3}$ in the mucosal injury and epithelial barrier disruption in DSS-induced acute colitis in mice. BMC Gastroenterol 2012; 12:57. doi: 10.1186/1471-230X-12-57.

62.Zhongxiang X., Jingtao C., Chao Z., Jing W., YunC., Shan Z., Chenhong L., Qingqing C., Jie Z., Tao J.: 1,25dihydroxyvitamin D3-induced dendritic cells suppress experimental autoimmune encephalomyelitis by increasing proportions of the regulatory lymphocytes and reducing Thelper type 1 and type 17 cells. Immunology 2017; 152(3): 414-424. doi: 10.1111/imm.12776.

Received: 10.12 .2020

Accepted: 15.02 .2021

Published online first: 27.04 .2021

This article is available in Open Access model and licensed under a Creative Commons Attribution-Non Commercial 3.0.Poland License (CC-BY-NC) available at: http://creativecommons.org/licenses/by-nc/3.0/pl/deed.en 